\title{
China, Eastern Europe and Russia compared ${ }^{* *}$
}

\author{
IVAN SZELENYI ${ }^{1}$ (1) and PÉTER MIHÁLYI ${ }^{2,3 *}$ (])
}

${ }^{1}$ William Graham Sumner Emeritus Professor of Sociology and Political Science, Yale University, New Haven, CT, USA

${ }^{2}$ Department of Economics, Corvinus University of Budapest, Fóvám tér 8, H-1093, Budapest, Hungary

${ }^{3}$ Department of Economics and Business, Central European University, Vienna, Austria

(c) 2020 The Author(s)

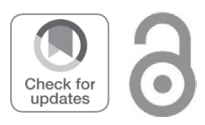

\begin{abstract}
After the collapse of the Berlin Wall it was conceivable that China would follow the path towards the cessation of communism, as it happened in the successor states of the USSR, Yugoslavia and the East European satellite states of the Soviet Union. But the Communist Party of China (CPC) managed to retain control and avoided the Russian and East European collapse, a full-fledged transition to capitalism and liberal democracy. For a while, China was on its way to market capitalism with the possible outcome to turn eventually into a liberal democracy. This was a rocky road, with backs-and-forth. But the shift to liberal democracy did not happen. The massacre at Tiananmen Square in 1989, approved by Deng Xiaoping, was a more alarming setback than the contemporary Western observers were willing to realize. This paper presents an interpretation of the changes under present Chinese leader, Xi Jinping in a postcommunist comparative perspective.
\end{abstract}

\section{KEYWORDS}

China, liberalism, illiberalism, dictatorship, comparative economics

\section{JEL CLASSIFICATION INDICES}

B14, P11, P14, P21

*Corresponding author. E-mail: peter@mihalyi.com

${ }^{\star *}$ Based on a video message prepared (but not presented) for the Conference commemorating the 40th anniversary of launching of Chinese reform and 30th anniversary of the publication of path-breaking paper by Victor Nee "Market transition theory", Renmin University (Beijing), August 27-28, 2019. 


\section{INTRODUCTION}

Market mechanisms were rarely totally eliminated in the socialist economies. They typically were subordinated to the dominant redistributive integration mechanism of the society. In some epochs and in some countries, markets played a significant secondary role. An early instance was the "New Economic Policy" (NEP) of the USSR in the 1920s. Yugoslavia opened space for more market since the 1960s. Arguably the most consistent concessions to market forces were made in Hungary between 1963 and 1989. During the 1980s, the authors of this paper independently from each other (Mihályi 1983; Szelenyi 1988) considered that Hungary was on its way to a "socialist mixed economy" in which the enterprise sector remained in government ownership and under redistributive integration, but small entrepreneurs emerged from collective farmers and employees in the redistributive sector were eventually allowed to earn incomes from (often semi-legal) "side-jobs." Ironically this produced an unanticipated outcome as far as social inequalities are concerned (Szelenyi 1978). While in primarily market-integrated economies the major source of inequality is the market itself (compensated by redistributive intervention of the welfare state), in socialist mixed economies redistribution created the inequalities and the poor had to try to compensate for this by market transactions. In retrospect, we know that this type of socialist mixed economy was unsustainable, a dead-end street, doomed to failure, which happened in 1989-1991 virtually everywhere in Central and Eastern Europe as well as in the USSR.

China, in December 1978, entered an early process of market transition, which at least between 1978 and 1985 was somewhat similar to the Hungarian model. Most importantly - and surprisingly for economic theorists of inequality - during the first seven years, social differences declined in China. The essence of early reform was careful, gradual de-collectivization (Fan et al. 2019). It allowed collective farmers to work in their family work-organization, with fewer and fewer production quota and to sell their products at gradually liberalized prices on the farmer's markets. Hence, the big winners of these early reforms were the rural direct agrarian producers. The Chinese reform was eventually broadened to other actors. In particular, the role of Township and Village Enterprises (TVE) (Zhang 1999) grew over the years. TVEs were initially defined as cooperatives involved in activities beyond agrarian production and with ambiguous property relations, where the local cadres (the state-party nomenklatura ${ }^{1}$ ) joined the beneficiaries, and eventually became the major winners. And indeed, after 1985, social inequalities began to grow again. This was the time, when the Chinese model started to face a major ideological challenge "from the inside." President and General Secretary Gorbachev promulgated the concepts of glasnost, uskorenie and perestroika. He also started to democratize the communist party itself. In June 1988, Gorbachev convened the 19th Party Conference, where the

\footnotetext{
${ }^{1}$ The term nomenklatura (originally a value-free Russian word, borrowed from Latin, meaning a list of names) was widely used in the Soviet Union. In all former socialist countries (including China), it meant a category of people who held various key administrative positions in the bureaucracy, running all spheres of society: government, industry, agriculture, academia etc., whose positions were granted only with the approval of the communist party of the country. Virtually all members of the nomenklatura were members of the Communist Party. Nomenklatura is a similar concept to the western "Establishment" holding or controlling both private and public powers (e.g., media, finance, trade, industry, state and institutions). In other words, nomenklatura is a broader concept than "elites." For the Chinese context, see Xu (2019).
} 
proceedings were televised, and for the first time since the 1920s, voting was not unanimous. In May 1988, János Kádár, the Hungarian communist party leader since 1956, was forced to resign and a new generation of reformist leadership came into power. In Poland, a massive wave of workers' strikes broke out in 1988. The strikes, as well as street demonstrations shook the communist regime to such an extent that it was forced to begin talking about recognizing the Solidarity opposition movement.

Thus, it was conceivable that China would follow the path towards the breakdown of communism too, as it happened in Russia and Eastern Europe. But the Communist Party of China (CPC) managed to retain control and avoided the Russian and East European collapse, a full-fledged transition to capitalism and liberal democracy.

Victor Nee in his path-breaking paper (1989) on "market transition theory" developed a vision of market economy with winners and losers distributed over the whole social hierarchy without posing the question whether this will be "capitalism," or a "transition to democracy" will have to follow the transformation. Hence, we do have here an elegant and precise theory of market transition without assuming that it inevitably implies making of capitalism and liberal democracy. This paper set the agenda for research on China for one or two decades. In fact, this agenda - the existence of "the third way" - is more important today than any time since 1978 (Heyets - Grytsenko 2019; Nuti 2019).

\section{THREE DIVERGENT PATHWAYS AFTER 1988-1991}

The critical point of our paper is that the countries which identified themselves for decades as "socialists" entered divergent trajectories. In our recently published book (Szelényi and Mihályi 2020) we identified three market transition pathways from the socialist redistributive (centrally planned) economies. Such divergences were unanticipated since during the socialist times all these countries seemed to be on a convergence trajectory. ${ }^{2}$

As we mentioned already above, in 1989-1991, the previous system of the European socialist countries spectacularly broke down. They all were heading towards capitalism, and most of the Central European countries moved towards liberal democracy, as well. In June 1989, China was at a turning point too, but rather than turning towards liberal democratic capitalism, she moved away from the reforms of 1978. It was only after the "Southern tour" of Deng Xiaoping in early 1992, when this 88-year old communist veteran managed to persuade the other leaders to return to the road of the reform, but without a full-fledged transformation to capitalism and/or liberal democracy.

So, China insisted on remaining "market socialist with Chinese characteristics" and at least until 1998-1999 it looked like capitalism from below. One of the authors of this paper (Szelenyi 2010) analyzed the social origins of the top 10 Chinese wealthiest people and found that only one of them came from the elite, while all the others came from humble origins (farmers, bricklayers, etc.). Several Chinese researchers - e.g. Lu (2017) and Fan - Lu (2019) - found similar tendencies though they reported a much more diverse background for the Chinese new rich.

\footnotetext{
${ }^{2}$ With the benefit of hindsight, one should have paid more attention to the fact that China, after she clashed during the late 1960's with the USSR both ideologically and militarily, followed its own course in many ways.
} 
In our new book, mentioned already above, we suggest that by the year 2000, many of the former European socialist countries imported capitalism from the outside. In other words, the capitalist transformation was driven by foreign direct investments (FDI) - first in Hungary but soon followed by Poland, Slovakia, the Baltic states and recently Romania. The commitment to the ideals of liberal democracy and the European Union was especially strong in what commonly was called Central Europe (the "Visegrad-4" and the Baltic states, the former sphere of German influence).

The third pathway we observed in Russia and we labeled it capitalism from above. This meant - inter alia - state-led privatization, offering advantages to clients of the political elites (or even enriching the elites and their families). Unsurprisingly, the former Soviet Republics in Central Asia followed the Russian model closely.

As China began to enter into the privatization of the state-owned enterprise sector in 19981999 and the social composition of the wealthiest Chinese began to change as well with the "princelings" accumulating substantial private wealth, we began to wonder, whether China is not converging to the Russian way of transition from above. Victor Nee already, in 1989, speculated about a hybrid state in China but reconfirmed his faith in the "capitalism from below" model in his wonderful book (Nee - Opper 2012), emphasizing the dynamic character of private entrepreneurship in Chinese development. Nevertheless, the official doctrine in China remained "socialism with Chinese characteristics."

\section{RE-CONVERGENCE IN ILLIBERALISM? IS THIS PUTIN'S OR PRESIDENT XI'S MODEL?}

\subsection{Recentralization in China}

China, of course, was never a liberal democracy - never claimed to be one and always rejected to be called capitalist. Those who believed that China actually did become capitalist, however, typically accepted that she would become eventually a liberal democracy as well, because they were convinced that capitalism can only co-exists with liberal democracy.

Western liberal economists proved to be naïve, to say the least. Today, more than 40 years after the beginning of market reforms in China, we can confidently assert that she is nowhere near to the Western concept of liberal democracy. In June 1989, China made a clear commitment to resist the temptation of liberal democracy. Whether in any meaningful way she became capitalist is still hotly debated mostly by Chinese, but also by some Western scholars. Can a country ruled by a Communist Party be called capitalist? This question directly follows from the magnum opus of János Kornai, entitled The Socialist System (1992), which defined "socialism" with three equally important building blocks: (i) public ownership of the means of production, (ii) redistributive integration of the economy and (iii) the rule by a communist party. ${ }^{3}$

China undoubtedly experiences some degree of "liberalization" (especially in the business world there was substantial change towards the "rule of law"). For example, in rural communities already, in the 1990s, a corporatist arrangement emerged between local government, business and popular interests (Oi 1992; Lin 1995). But China has certainly not been turning

\footnotetext{
${ }^{3}$ As a matter of fact, Kornai put the unlimited rule of the communist party on the very first place.
} 
into a "legal rational authority" and never considered nationwide elections to the legislature or anything resembling universal suffrage. Nevertheless, there has been some significant "internal democracy within the party" (promoted by President Hu, in office between 2003 and 2013):

(i) The Standing Committee of the Politburo, consisting of 5-11 members, exercised substantial influence and articulated various interests,

(ii) the country's President had a term limit, could be elected only twice, he shared some power with the prime minister, and

(iii) their successors were appointed early, and then they played some role during the second term of the President and Prime Minister.

On the contrary to the above said, in China recently we saw the reinforcement of central authority. While during the 1980s there was substantial decentralization (Yang 2016) during the latter part of the present decade, the authority of the central executive branch has been substantially increased. An important move in the same direction was when the constitution was amended in 2018 to allow the President to serve for life, without any term limit. Many commentators believe that the President and CPC General Secretary Xi has more authority than anyone had since Mao, and probably, he has more influence on the Standing Committee than previous party presidents. Recentralization and reinforcement of the authority of the CPC were, on the other hand, not a "break" just a continuation of the Chinese way of "power-sharing."

In Russia, by contrast, after 2000 and in some Central European countries during the past 10-15 years, there has been a rather clear shift from the way they experienced transformation after 1989-1991. This shift was primarily in politics, but with some implications for the economy, as well. To be clear, the capitalist nature of post-1989-1991 Russia or Central European capitalism was never in doubt, but given the important changes in the political system, arguably the way how their capitalist economy functions is deeply affected.

\subsection{Changes in Russia: from Yeltsin's "wild East capitalism" to Putinism}

Let us first address the question of political-economic changes. In this respect, the first 10-15 years of transformation was quite different in Russia. President Yeltsin's system created a "wild East" type of capitalism. Russia was committed to rapid changes in property relations without much possibility of interference for foreign investors. Yeltsin's political slogan was "we do not want to create a few millionaires, but we aim at the creation of millions of owners." The major mechanism of privatization was by privatization checks (vouchers or coupons), which eventually led to the emergence of a rather small class of oligarchs. While public property was distributed broadly among the population, most recipients without experiences of entrepreneurship and capital, sold their vouchers to a few people, well connected to the Kremlin who in publicly manipulated auctions de facto appointed a new grand bourgeoisie from people whom they expected to support them politically. Yeltsin acted as the "Godfather of the Kremlin," to put it in terms developed by Paul Klebnikov (2000). These oligarchs soon began to privatize the state itself, which led to state failure at grand scale and to an anarchic, oligarchic type of capitalism. While Yeltsin during his first one or two years of his presidency appeared to be sympathetic to liberal democracy, he soon clashed with the democratically elected Parliament (the Duma) and

\footnotetext{
${ }^{4}$ This is a term we borrow from the German 19th-century sociologist, Max Weber.
} 
shut down the constitutional court, hence there was no democratic opposition to the oligarchic chaos which followed.

Vladimir Putin, in 1999-2000, took over a failed state and a bloody war in Chechnya. Very early on it became clear that he would crack down with an iron hand on those oligarchs, who were not his loyal followers. While during the first few years of his presidency Putin was perceived by many Western commentators as a reformer aiming at market capitalism and liberal democracy, soon it became clear that he instead tried to establish himself as the "good tsar," creating a strong executive with virtually no divisions of power. He promised to "make Russia great again," to restore it greatness of the Tsarist times. In his aspirations, he found an ally in the Orthodox Church.

While the price of oil was booming, a large middle-class benefitted from his strong executive will. But as the economy was turning down, he needed to gain popular support with an appeal to Russian ethno-nationalism, orthodoxy and imperial ambitions as it became obvious with the annexation of the Crimea and the proxy war in the Ukraine and other foreign policy adventures (including intervention in the 2016 US election). Putin is not restoring the USSR (his ideal is Tsarist Russia), nor does he restore socialism. He established a firm executive control over the political process.

He basically runs a "one-party system," and while multi-party election takes place regularly, they are highly managed in favor of the United Russia party, with no substantial organized opposition whatsoever. The executive branch has almost complete control over the judiciary, and while opposition media is marginally tolerated, opposition journalist and politicians are threatened (occasionally killed under unclear circumstances). Private wealth is respected, but also increasingly under the control of the executive with occasional re-nationalizations and advantages offered to rent-seekers ${ }^{5}$ of loyal entrepreneurs or even family members. Putin created a system which looks very much like what Hungarian Prime Minister, Viktor Orbán (2014) called in a famous speech in 2014 "illiberalism."

\subsection{The rocky roads of European former socialist countries from liberal democratic capitalism to illiberalism (1990-2005, 2006-2019)}

This takes us back to the former socialist countries of Europe. In the above-mentioned talk, President Orbán launched an attack against "liberalism." In his view, liberalism puts excessive emphasis on individual liberties and does not represent the national interest effectively. Hence, he recommended replacing "liberal democracy" with "illiberal democracy." In liberal democracies, particularistic interest can delay or even block practical executive actions for the national interests. In Orbán's vision, illiberal democracy retains regular multi-party elections, but much like in Putin's version it assumes a system of "national cooperation," with a strong "central force field" by his own party, called Fidesz. ${ }^{7}$ The essence of the system is an effective

\footnotetext{
${ }^{5}$ See more about this in Mihályi - Szelényi (2019).

${ }^{6}$ Most recently Orbán (2019) identified this as "Christian," rather than "individual" freedom, claiming that Christian democrats are also "illiberals," what no West European Christian Democratic Party would accept.

${ }^{7}$ Fidesz is a Hungarian Civic Alliance, the right-wing populist ruling party in Hungary. Founded in 1988 as a liberal youth party opposing the ruling communist government, Fidesz has come to dominate Hungarian politics on the national and local level since its landslide victory in the 2010 national elections with an ethno-nationalist agenda. Viktor Orbán has been the leader of the party for most of its history, including the liberal period.
} 
executive branch, which is not limited or paralyzed from time to time by other branches of powers, like the judiciary, media or even social science research - as according to Orbán may be the case in liberal democracies. This illiberal regime is deeply capitalist, but the economy much like the political arena - is "managed." The most important mechanism for such "management" is the regulation of the markets - especially investment markets (including public procurements). Since the executive is supposed to have privileged knowledge of what market outcomes are in the national or common interests, it can give market advantages to those actors who are supposed to act for such interests. One is not supposed to leave market transactions to blind profit-seeking behavior. The ones selected for a privileged position on those regulated markets (for instance domestic players versus foreign investors, among domestic players those who are more trustworthy for the executive and in particular for the chief of the executive branch) are rewarded by rents, rather than just receiving profits for their entrepreneurial spirits. This way, the profit-seeking behavior of market actors is replaced by rent-seeking. When the selection of awardees of such rents is based on bloodline or adapted family kinship of the chief of the executive, such choices may be called "corruption." This Hungarian system based on these grounds was labeled by a Hungarian sociologist (and former Minister of Education), Bálint Magyar (2013) as "mafia state."

\section{POSTSCRIPT: AN ILLIBERAL INTERNATIONAL? THE SCOPE AND LIMITS OF ILLIBERAL CONVERSION AND GLOBAL CAPITALISM}

The tendency to liberate the executive and especially the chief of the executive from paralyzing forces of particularistic interests and the transition from liberalism to illiberalism may have been invented by President Putin (or President Xi, or even some of his predecessors), but this is a trend well beyond those two big countries. Among the former socialist countries of Eastern Europe, Hungary follows closely such a political and economic transformation, but the "Putin virus" is present, in most post-communist countries of Europe (in Poland, the Czech Republic, Romania, Bulgaria and most of the other Balkan states) and well beyond the post-communist world. The strengthening of the executive branch and the desire to enable it and its executive to act effectively what they define as the "national interest" is evident in Erdogan's Turkey, in Trump's USA, it drives the Brexiters in the UK, and clearly observable in Bolsonaro's Brazil or in Modi's India. Is the world entering now in an epoch of illiberalism? Is this the inverse of Fukuyama's "end of history" concept (1989), the final victory of liberal democratic market capitalism?

Hard to tell. We may experience a rather short-term cycle of political fortunes. Leaders of illiberal regimes gained electoral success by promising to defend ethno-national interests against the forces of globalization and "dry the swamp" of bureaucratic politics of liberal democracies. President Xi, Putin, Trump, Erdogan, Bolsonaro, Orbán or Modi can indeed act swiftly since they do not have to go through the painful, costly and lengthy process of negotiation with various interests. This looks like success.

Nevertheless, there are critical shortcomings of illiberal regimes as well. The speed by which decisions are made is not always matched by sufficient and sufficiently high quality and diverse information liberal democracies operate with. The swift, but not always the best-informed decision may not produce the best possible outcomes. Furthermore, while the appeal to exclusive 
ethno-national radicalism may be a formidable force to mobilize people (and electorates), but it contradicts the powerful - and possible overwhelming - forces of globalization. There can be only global answers to the crucial challenges the world is facing today: the coronavirus pandemic, the environmental degradation, the uneven demographic change across continents and the free flow of capital around the world. China first, Russia first, USA first, Hungary first etc. may help chiefs of executives to consolidate their power and even to win election at home if they seek elections at all - but they may not be the most appropriate foreign policies for the 21st century (Roland 2019). The forcefully acting executives with their exclusionary ethnonationalism eventually may have to settle once again with a more globalist view of our problems and sacrificing the speed of sovereigntist decisions for a nationally and globally more multilateral, slower, but at the end better informed process of decision making.

Fukuyama (1989) was right on target. Indeed, for the following 15 years as the Freedom House Institute reported, the number of countries which were classified as "free" was increasing and the proportion of "unfree countries" declined. But then, President Putin in his annual address in December 2013 called for a formation of a new "international" around his policies. Nowadays, liberal democracies are retreating, and illiberal regimes are ascending. In May 2019, European anti-migrants, exclusionary ethno-nationalist from the Italian Salvini to the French Marie Le Pen and Orbán from Hungary were all hoping in a major breakthrough and the formation of a large enough fraction of their own in the European Parliament so they can shape European politics. While their parties did well at home, and both the social democrats and the people's parties lost ground, the big winners were the greens and liberals. The prospects of an illiberal international are not great today. Their main protagonists are all nationalist with particularistic national (and imperial) interests. Trump - occasionally - expressed admiration (even love) for Putin and Xi, but the US, Russia and China have structural/imperial conflicts. Salvini and Orbán equally hate "migrants," but Salvini would like to send them from Italy to Hungary (and to other European countries), what is the least that Orbán wants. The Polish strong man, Jaroslav Kaczynski is just as illiberal as Orbán, but the Poles intensively hate Russians, while Orbán's Hungary is Russia's best friend in the European Union. In other words, ethno-national illiberalism and illiberal internationalism are direct contradiction in terms. Only transnational liberalism can be international and address in multilateral ways the global challenges of the world.

\section{REFERENCES}

Fan, X. - Lu, P. (2019): The Social Composition of China's Private Entrepreneurs. Social Sciences in China, 40(1): 42-62.

Fan, G. - Ma, G. - Wang, X. (2019): Institutional Reform and Economic Growth of China: 40-year

Progress Toward Marketization. Acta Oeconomica, 69(S1): 7-20.

Fukuyama, F. (1989): The End of History? The National Interest, No. 16 (Summer): 3-18.

Heyets, V. - Grytsenko, A. (2019): “Tertium Datur” by Grzegorz W. Kolodko. Acta Oeconomica, 69(S1): 21-30.

Klebnikov, P. (2000): Godfather of the Kremlin. New York: Harcourt.

Kornai, J. (1992): The Socialist System. Princeton: Princeton University Press. 
Lin, N. (1995): Local Market Capitalism: Local Corporatism in Action in Rural China. Theory and Society, 24(3): 301-354.

Lu, P. (2017): The Horatio Alger Myth in China. China: An International Journal, 15(2): 4-26.

Magyar, B. (2016): Post-Communist Mafia State - The Case of Hungary. Budapest: Noran Libro Publisher.

Mihályi, P. (1983): Das Ungarische Modell. Osteuropa Wirtschaft, 28(2): 138-146.

Mihályi, P. - Szelényi, I. (2019): Rent-Seekers, Profits, Wages and Inequalities - The Top 20\%. Palgrave MacMillan.

Nee, V. (1989): A Theory of Market Transition. American Sociological Review, 54(5): 663-681.

Nee, V. - Opper, S. (2012): Capitalism from Below. Cambridge: Harvard University Press.

Nuti, D. M. (2019): The Chinese Alternative. Acta Oeconomica, 69(S1): 31-47.

Oi, J. C. (1992): Fiscal Reform and the Economic Foundation of Local State Corporatism in China. World Politics, 45(1): 99-126.

Orbán, V. (2014): Full Text of Viktor Orbán’s Speech at Băile Tuşnad of 26 July 2014. https:// budapestbeacon.com/full-text-of-viktor-orbans-speech-at-baile-tusnad-tusnadfurdo-of-26-july-2014/, accessed on 2 February 2019.

Orbán, V. (2019): Prime Minister Viktor Orban's speech at the 30th Summer Open University and Student Camp at Băile Tuşnad on 27 July 2019. http://www.miniszterelnok.hu/prime-minister-viktor-orbansspeech-at-the-30th-balvanyos-summer-open-university-and-student-camp/.

Roland, G. (2019): Coexisting with China in the 21th Century. Acta Oeconomica, 69(S1): 49-70.

Szelenyi, I. (1978): Social Inequalities in State Socialist Redistributive Economies. International Journal of Comparative Sociology, 19(1-2): 63-87.

Szelenyi, I. (1988): Socialist Entrepreneurs. Cambridge: Polity Press.

Szelenyi, I. (2010): The New Grand Bourgeoisie Under Post-Communism: Central Europe, Russia and China Compared. UNU Wider Working Papers, No. 2010/63.

Szelényi, I. - Mihályi, P. (2020): Varieties of Post-Communist Capitalism. A Comparative Analysis of Russia, Eastern Europe and China. Leiden, The Netherlands: Brill.

Xu, C. (2019): The Pitfalls of a Centralized Bureaucracy. Acta Oeconomica, 69(1): 1-16.

Yang, Z. (2016): Tax Reform, Fiscal Decentralization and Regional Economic Growth: New Evidence from China. Economic Modelling, 59(December): 520-528.

Zhang, Z. (1999): Rural Industrialization in China. From Backyard Furnace to Township and Village Enterprises. East Asia, 17(3): 61-87.

Open Access. This is an open-access article distributed under the terms of the Creative Commons Attribution 4.0 International License (https://creativecommons.org/licenses/by/4.0), which permits unrestricted use, distribution, and reproduction in any medium, provided the original author and source are credited, a link to the CC License is provided, and changes - if any - are indicated. (SID_1) 